\title{
Increased Productivity of Oyster Mushroom Chips Through Business Management, Finance, and Handling Post-Harvest Management
}

\author{
Yani Suryani ${ }^{1}$, Maimunah Siregar ${ }^{2}$, and Desi Ika ${ }^{3}$ \\ ${ }^{1,3}$ Universitas Harapan Medan, \\ ${ }^{2}$ Universitas Pembangunan Panca Budi
}

\begin{abstract}
The community subjection activities is a partnership program between the Community Partnership Program (PKM) with Dolok Masihul (Domas) Farmer Group partners. The problems are (1) Production aspects include a) Oyster mushroom chips are oily and less crunchy and do not last long; b) Plastics and labels used are still inadequate and straightforward because they are not accompanied by product information as well as packaging for oyster mushroom chips which is even done manually. (2) Aspects of Business and Financial Management, among others: a) Marketing is still carried out conventionally. b) Business management is always simple, carried out in a family manner, and there is no product legality. c) There is no separation between household finances and business finances. d) There are no records or business bookkeeping so that it is difficult to calculate the profits it gets. This community service aims to increase the knowledge, skills, and income of the Domas Farmer Group and the surrounding community through training in production, finance, and marketing. Community service activities are carried out using method 1). Transfer of knowledge, such as lectures and discussions, 2). Training, and 3). Bookkeeping assistance for the Oyster Mushroom Chips business. The results to improve the skills and knowledge of the Domas farmer group include making Oyster Mushroom chips using Deep Fryers and Spinners, knowing the use of social Media for marketing, and being able to make a financial report_- publishing the Compilation Guide Book.
\end{abstract}

Keywords: Poktan Domas Creative and Productive

Abstrak. Kegiatan pengabdian masyarakat yang dilakukan adalah Program Kemitraan Masyarakat (PKM) dengan mitra Kelompok Tani Dolok Masihul (Domas). Permasalahan yang dijumpai pada usaha mitra adalah (1) Aspek Produksi meliputi a) Keripik jamur tiram berminyak dan kurang renyah serta tidak tahan lama; b) Plastik

*Corresponding author at: Universitas Harapan Medan

E-mail address: 
dan label yang digunakan masih sederhana dan belum memadai karena tidak disertai dengan informasi produk begitupun dengan pengemasan keripik jamur tiram yang masih dilakukan secara manual. (2) Aspek Manajemen Usaha dan Keuangan antara lain : a) Pemasaran masih dilakukan secara konvensional. b) Pengelolaan usaha masih sederhana dilakukan secara kekeluargaan dan belum ada legalitas produk c) Belum ada pemisahan antara keuangan rumah tangga dengan keuangan usaha d) Belum ada catatan atau pembukuan usaha sehingga kesulitan dalam menghitung keuntungan yang diperolehnya. Tujuan dilakukan pengabdian masyarakat ini adalah untuk meningkatkan pengetahuan, keterampilan dan pendapatan Kelompok Tani Domas serta masyarakat sekitarnya melalui pelatihan bidang produksi, keuangan dan pemasaran. Kegiatan pengabdian masyarakat dilakukan dengan metode 1). Transfer pengetahuan seperti ceramah dan diskusi, 2). Pelatihan, dan 3). Pendampingan penyusunan pembukuan untuk usaha Keripik Jamur Tiram. Hasil pengabdian masyarakat diharapkan dapat meningkatkan keterampilan dan pengetahuan kelompok tani Domas yang meliputi keterampilan membuat keripik Jamur Tiram dengan menggunakan Deep Fryer dan Spinner, telah mengetahui pemanfaatan media sosial untuk pemasaran serta dapat membuat pembukuan. Penerbitan Buku Panduan Penyusunan Laporan Keuangan untuk UMKM.

Kata Kunci: Poktan Domas Kreatif dan Produktif

Received 23 August 2020| Revised 22 November 2020| Accepted 25 November 2020

\section{Introduction}

This Oyster Mushroom cultivation business is one of the firms that has bright prospects and is very potential to be developed considering that at this time the opportunity for the market share of Oyster Mushrooms is quite large and tends to increase along with the increasing market demand for Oyster Mushrooms due to the rising public interest in consuming mushrooms Oyster. The still open market share of oyster mushrooms provides promising business opportunities for oyster mushroom farmers. [1] It is because the community increasingly understands the benefits and nutritional content of Oyster Mushrooms. Oyster mushrooms contain water, fibre, iron, calcium, vitamin B1, vitamin B2, and vitamin C, high protein content, rich in vitamins and minerals, low in carbohydrates, fats, and calories. The composition and nutritional content of every 100 grams of oyster mushrooms are 367 calories, 10.5-30.4 percent protein, 64.1 percent carbohydrates, 2.66 percent fat, $0.20 \mathrm{mg}$ thiamin, 4.7-4.9 mg riboflavin, $77.2 \mathrm{mg}$ niacin, and $314.0 \mathrm{mg}$ of calcium. The calories contained in this mushroom are $100 \mathrm{KJ} / 100 \mathrm{gram}$ with 72 percent unsaturated fat. Mushroom fibre is perfect for digestion. Because it has a low-fat content making it suitable for consumption by dieters [2]. 
This oyster mushroom has health benefits including, can reduce cholesterol and weak heart and some other diseases. This mushroom is also believed to have medicinal efficacy of various illnesses such as liver disease, diabetes, anaemia [3] Thus the cultivation of oyster mushroom in Blok 10 sub-district Dolok Masihul is one of the business opportunities that can increase income/income for business actors where the oyster mushroom does not know the season so that it can produce a continuous profit throughout the year. The cultivation of oyster mushroom is a business that does not require extensive land, and the maintenance process is easy and comfortable to obtain and cheap raw materials. The cultivation of oyster mushroom can be developed commercialized and have high economic value where the demand for oyster mushroom is relatively high and the need for household consumption also demand the processed food industry made from oyster mushroom raw, e.g. oyster mushroom chips.

The business of oyster mushroom conducted by Poktan Domas has bright prospects, but this is not accompanied by the stability of profit/increase in profits. There is still a lack of knowledge of farmers or partners managing a profitable business where partners' business management is even done in a family. It has not been done bookkeeping or business registration of partners that separates the company with household finances.

Poktan Domas has a desire to develop oyster mushroom and oyster mushroom chips cultivation businesses by learning how to manage business and business finances, make business financial statements/reports so that it can increase business capital. High market demand gives a pretty bright picture of oyster mushroom cultivation. This mushroom business opportunity is tremendous due to public awareness of the value of health. By consuming oyster mushrooms can provide health benefits.

The problems faced by partners include the issue of oyster mushroom chips production capacity, business and finance management, post-harvest handling, and marketing are still carried out conventionally. It causes the partners to have difficulties in meeting market demands and improving their business. Partners strongly desire to develop their business, overcome and increase their knowledge.

\section{Method}

The method of implementing the Community partnership Program and based on the priorities of the partners, following the expertise owned by the team of proposals/executor activities and agreements with the partner, then the solution approach is to solve the problem of production aspects primarily related to product quality, post-harvest handling, and management, product marketing, making better 
packaging with label and product information, the legality of products in the form of license PIRT and MUI Halal certificate and drafting of books/financial statements following financial accounting standards-micro, small and medium enterprises.

The working procedure to support problem-solving is using training, education, and partner mentoring. For such partners will be given a questionnaire before and after training to measure the level of understanding of partners. Hopefully, after the activities of this community partnership program are completed, this partner can independently do oyster mushroom cultivation, post-harvest handling and marketing are increasing because it has produced products that already meet the quality and quantity, and legality of products. The partners and the executive team will gather in a place for material delivery as well as direct practice by the problems that will be completed.

The solutions and methods used in the implementation of PKM to address the problem of priority partners can be seen in the following schemes:

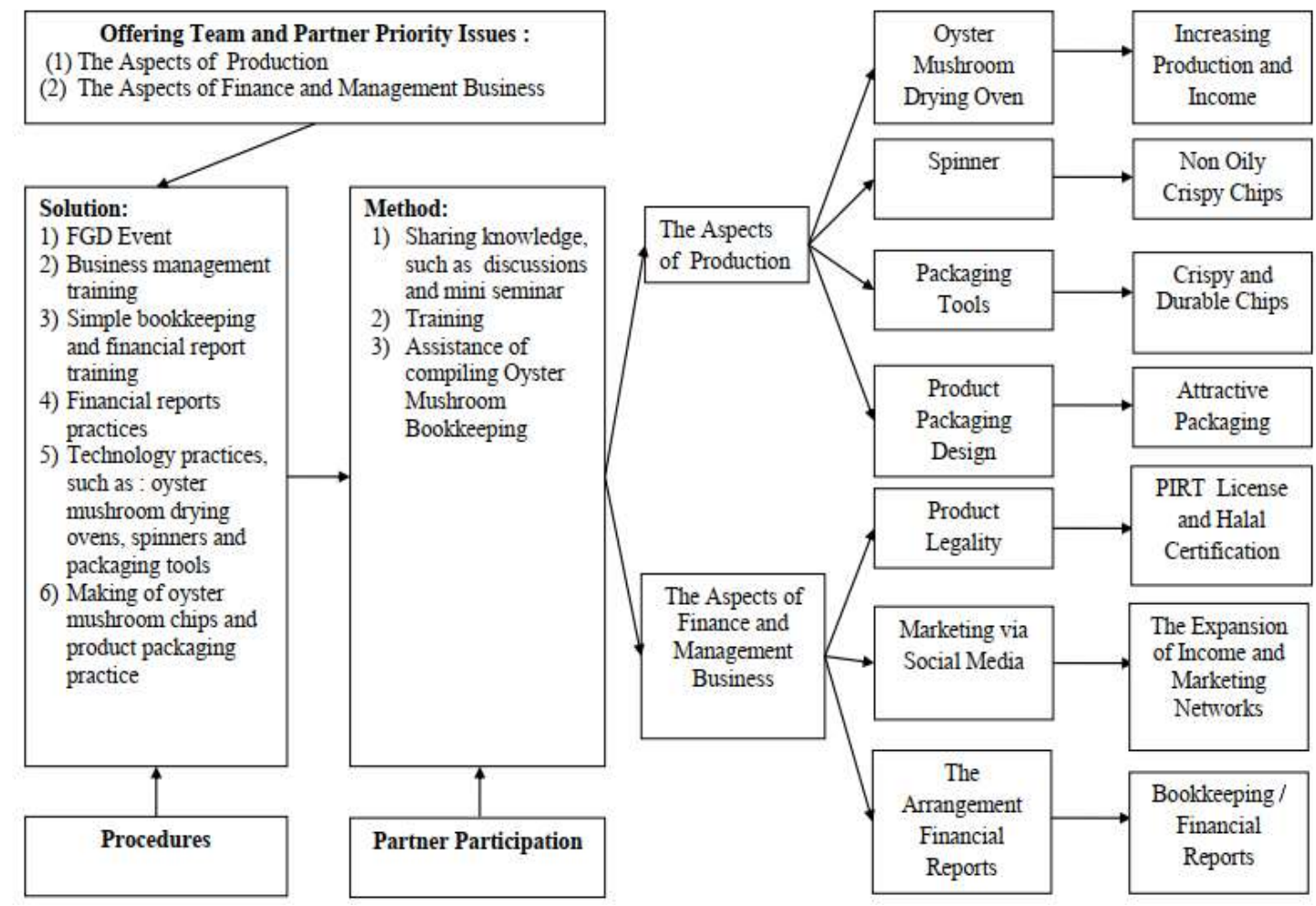

The success of this PKM implementation requires partner participation in this activity so that the problem of priority partners can be solved well. The participation of partners in this activity include:

1. The disclosure partner in providing the required information relating to the resolution of the partner's priorities. 
2. The willingness of partners to provide a place when activities are implemented under the program is made by the team of proposals and approved partners.

3. An active role in any activities undertaken.

4. Willing to do maintenance to the tool later given the proposal team.

5. Participate in the implementation of evaluation and monitoring activities.

\section{Evaluation of activity implementation and Program sustainability}

To determine the success or absence of a program, it is necessary to evaluate the program's implementation. To assess the program's success and sustainability, which can also be used as a tool for the improvement of the program, the proposed team evaluated by providing questionnaires before and after the implementation of the activities. The purpose of an evaluation is to be able to know the success rate of the program implementation. It can overcome the obstacles that may occur during the performance of activities.

\section{Result and Discussion}

Community subjection activities are carried out to increase the knowledge, skills, and income of the Domas Farmer Group and the surrounding community in Blok 10 Village, Dolok Masihul District through training in production, finance, and marketing. Production training is making oyster mushroom chips using a Deep Fryer and a spinner so that the oyster mushroom chips are crispy and durable. They are creating an attractive label and packaging designs and product legality. It is done to improve the quality of the oyster mushroom chips produced by the Domas farmer group. Small and medium enterprises face a common problem because chip products still use simple packaging, are not durable, and do not have a label [4].

Financial training in the form of financial reporting to increase Poktan Domas business productivity through sound financial management. One of the crucial factors in business development is bookkeeping [5]. Furthermore, training in marketing in the form of using social media to market oyster mushroom chips to promote oyster mushroom chips. It is expected to increase sales and expand the marketing area, which is supported by the results of research by Achmad et al. that using social media can open business opportunities that can increase product sales [6].

Some activities that have been implemented include:

(1) Training/discussion to create packaging design and label of oyster mushroom chips. Activities Create packaging design designs and label oyster mushroom chips. At this meeting discussed/designing the packaging of better oyster mushroom chips 
equipped with labels Oyster mushroom chips in which there is product information so that it can help promote/introduce products that can attract consumers to buy.

(2) Training, the practice of oyster mushroom Post Harvest Management and provide a briefing to Mitra on how to use the Deep Fryer Gas machine, Spinner and Packaging equipment, and handover goods-goods. Training in handling the management of post-harvest managing. On this occasion, the delivery of a goods-the form of appropriate technology is the Deep Fryer Gas Machine, the right technology for Spinner, packaging equipment, and packaging and labels. The training material presented on this occasion is how post-harvest handling further post-harvest management Oyster mushroom delivered on this occasion is by processing oyster mushrooms into oyster mushroom chips directly practised way of manufacture. The practice of processing oyster mushroom into chips by observing the manufacturing process begins with seasoning making, in hopes that the fragments produced can be liked by consumers. Next cut the mushrooms and wash them. The washed mushrooms are rolled up and squeezed then gradually inserted into the seasoning powder formulated. The next process of frying mushrooms that have been mixed with seasoning flour where the frying process is using the appropriate technology in the machine Deep Fryer Gas. After ripe, the chips are lifted and inserted into the Spinner. Frying Oyster mushroom chips using Deep Fryer Gas produces oyster mushroom chips that are crisp and durable. After frying the next process, oyster mushroom chips are inserted into the appropriate technology to Spinner to reduce the oil level in the oyster mushroom chips so that durable is not easy to smell (Figure 1).

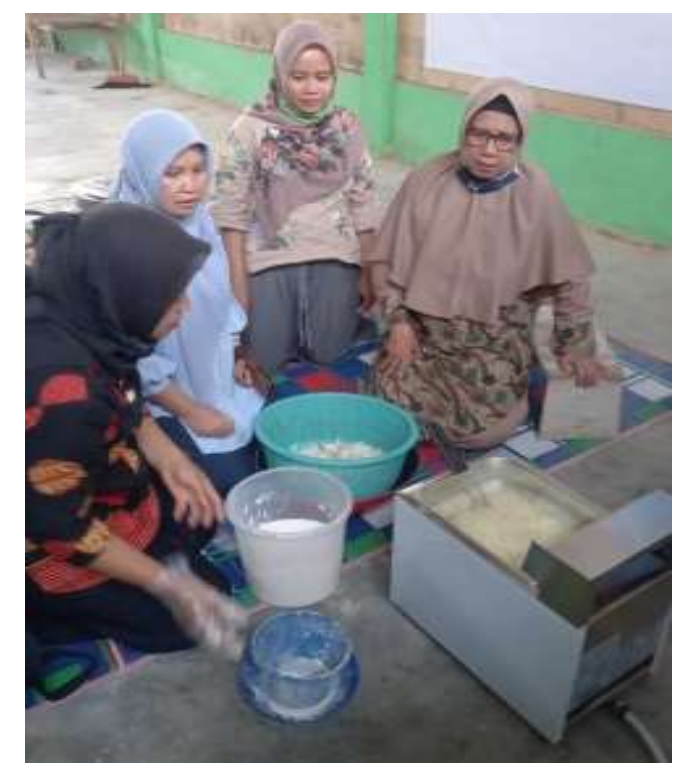

Figure 1. The practice of oyster mushroom chips making 
The next process is the packing of oyster mushroom chips where the newly-pressed oyster mushroom chips from the Spinner are cooled briefly afterward inserted into the labeled packaging that has been prepared and the using the Handsealer so that the oyster mushroom chips are durable/not easy to get into the wind (Figure 2).

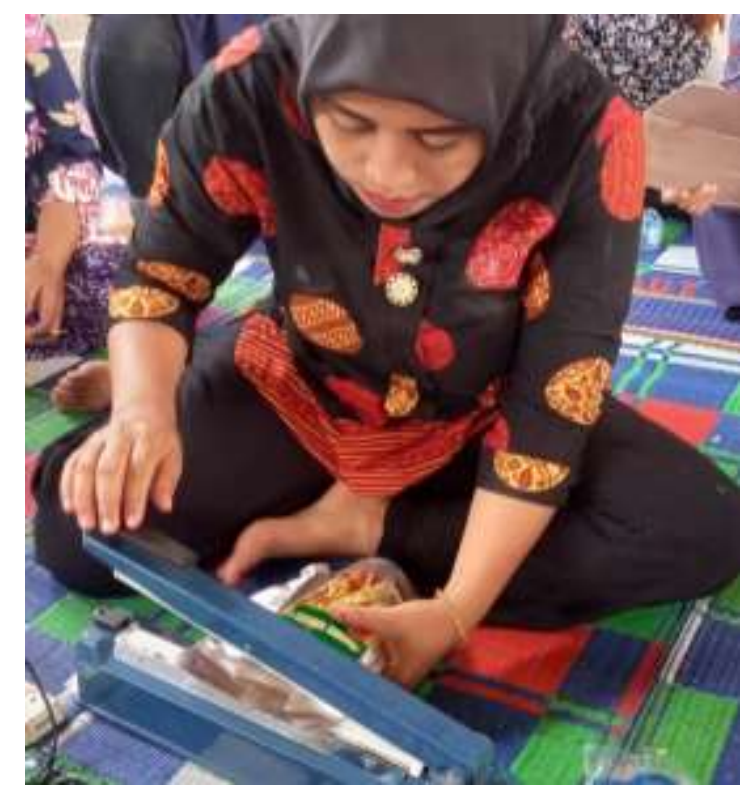

Figure 2. Demonstrating Packaging

(3) Marketing training through social Media is implemented with the aim that the group of oyster mushroom farmers in particular and local people has the knowledge and ability to utilize the existence of social media to increase sales/marketing oyster mushrooms and processed food oyster mushroom in the form of oyster mushroom chips. The training was told about the introduction of social media for marketing, e.g. Facebook, Instagram, and other marketing that could be used or utilized for product marketing. Using social media, the barriers of distance, space, and time and the price of goods can be eliminated [7]. Besides, using social media, farmers of oyster mushroom Domas do not need a large space to display oyster mushrooms or oyster mushroom processed food. But it is also explained that social media is just a tool in marketing the product. Each trainee in this mushroom farmer, oyster Domas should still have strong knowledge in doing business/marketing products.

(4) Business Bookkeeping Training (Journal of purchase, sale, acceptance, and withdrawal of cash) and training of financial statement preparation. The organizing of bookkeeping is vital for every business person to support the success of its business. Bookkeeping is a systematic and routine recording activity of transactions within the company which includes transactions of goods purchases, sales of goods, 
cash receipts, and cash withdrawals[8]. Oyster mushroom farmers organize essential bookkeeping because often the business actors mix the finances of their business with their household's finances. It will complicate business actors in calculating their business profits. This training explained bookkeeping, which includes how to make the recording of purchases (Journal of Purchase), the form of purchase journals. The recording of assets is a process of collecting data and information relating to business actors' accounting of purchases [9]. With simple bookkeeping, mushroom farmers can know the number of purchases and sales daily, monthly even yearly. Can see the amount of liabilities/debts or receivables. It can also see the amount of cash in/income and expenses incurred every day, month, or year. Where periodically farmers of the Domas oyster mushroom can count the benefits of his business. The financial statements preparation material covers the drafting of balance sheet, Profit/Loss report, cash flow statement and capital Change report.

Various training has been carried out, then evaluated by providing questionnaires to the training participants to determine the participants' level of understanding towards the material that has been delivered. The evaluation results show an increase in partner knowledge about the use of deep fryers and spinners; Attractive packaging and label design; use of social media to market products; and conduct business bookkeeping and financial management.

\section{Conclusion}

Community subjection activities have been carried out by the objectives, namely to increase the knowledge and skills of the Domas farmer groups. More than $90 \%$ of Domas farmer groups can make Oyster Mushroom chips using Deep Fryer and Spinner, already know the use of social media for marketing, and can do bookkeeping.

\section{Acknowledgments}

Thank you to the Ministry of Research and Technology / National Research and Innovation Agency for funding this activity through the 2020 Community Service grant. We would also like to thank the LPPM of Harapan University in Medan for supporting the implementation of this activity and all parties who have helped in carrying out this activity. 


\section{References}

[1] N. Widyastuti, "Processing of Oyster Mushrooms (Pleurotus Ostreatus) as an alternative for nutritional fulfillment" J. Sains dan Teknologi. Indonesia., vol. 15, no. 3, pp. 1-7, 2019, doi: 10.29122/jsti.v15i3.3391. (In Indonesia)

[2] S. M. Sumarsih, Oyster Mushroom Seed Business. Jakarta: Penebar Swadaya, 2015. (In Indonesia)

[3] Susilawati and B. Raharjo, Technical Guidelines for Environmentally Friendly Oyster Mushroom (Pleurotus Ostreatus) Cultivation. BPTP Sumatera Selatan, 2010. (In Indonesia)

[4] N. F. Usdyana, I. Ahmad, and M. Yusuf, "Diversification of Oyster Mushrooms as Local Food in Women Farmers Group in Malua District, Enrekang Regency," J. Dedikasi. Masyarakat., vol. 1, no. 2, p. 59, 2018, doi: 10.31850/jdm.v1i2.290. (In Indonesia)

[5] W. S. Manoppo and F. A. O. Pelleng, "Training on Compilation of Financial Statements using Simple Bookkeeping Techniques for MSME Entrepreneurs in Malalayang District, Manado City, North Sulawesi Province," J. Adm. Bisnis, vol. 7, no. 2, pp. 6-9, 2018, doi: 10.35797/jab.7.2.2018.22029.6-9. (In Indonesia)

[6] Z. Abidin Achmad, T. Zendo Azhari, W. Naufal Esfandiar, N. Nuryaningrum, A. Farah Dhilah Syifana, and I. Cahyaningrum, "Utilization of Social Media in Marketing of UMKM Products in Sidokumpul Village, Gresik Regency," J. Ilmu Komunikasi., vol. 10, no. 1, pp. 17-31, 2020, doi: 10.15642/jik.2020.10.1.17-31. (In Indonesia)

[7] D. J. Priansa, Integrated Marketing Communication in the Age of Social Media, Cetakan I. Bandung: Pustaka Setia, 2017. (In Indonesia)

[8] W. Carl, J. M.Reeve, J. E.D, E. T. Wahyuni, and A. A. Yusuf, Introduction of Accounting I. Jakarta: Salemba Empat, 2017. (In Indonesia)

[9] Hery, Basics of Financial Statements Introduction, Jakarta: PT Grasindo, 2014. (In Indonesia) 